\title{
H. P. Scholte and the 1856 Presidential Campaign in Michigan
}

John H. Yzenbaard

IN 1846 HENRY (HENDRICK) P. SCHOLTE led a group of his Dutch co-religionists to lowa and settled his "Pella." The community prospered with Scholte taking an active role in ministering to the colonists in both spiritual and secular matters. His leadership abilities were such that, within a decade of his arrival in the United States, Scholte was asked by the leaders of the Democratic Party in Michigan to take a part in promoting the political fortunes of the party's candidates for the presidency, James Buchanan and John C. Breckinridge. The presidential campaign of 1856 was one of the liveliest contests in the history of American presidential elections. ${ }^{1}$ It witnessed the emergence of a party consisting of diverse elements with a common goal-opposition to the further spread of slavery-as opposed to a national party running a "safe" candidate. As Professor Allan Nevins has pointed out, "Little part was played in the campaign by issues secondary to slavery." It was a campaign in which the ethnic vote was cultivated and one in which the foreign language press took an active part.

It was a common feeling among the Democratic politicians of Michigan that the possibility of winning, on both the state and national level, was slim indeed. In 1852 the party had been strong enough to win the governorship, when Robert McClelland defeated

\footnotetext{
${ }^{1}$ An interesting account of the campaign may be found in Allan Nevins, Ordeal of the Union (2 vols.; New York: Charles Scribner's Sons, 1947), II, 488-511. Richard Dana wrote a friend, ". . . for genuine inspiration 1840 couldn't hold a candle." Herman Van Holst, Constitutional History of the United States, (7 vols.; Chicago: Callaghan and Company, 1885), V, 451, ftnt.

${ }^{2}$ Ibid., 501
} 
the candidates of the Whig and Free Soil parties. ${ }^{3}$ Two years later the recently organized Republican Party had been most successful in its first campaign, winning a substantial majority of state offices. The Kansas-Nebraska Act, "Bloody Kansas," and "Bleeding Summer" had so affected the residents of the state that Michigan was to be a Republican stronghold for the next three quarters of a century. When President Pierce vetoed a bill which would have provided for the dredging of the St. Clair River "Flats," many Michigan Democrats were chagrined, including the Detroit Free Press, a pro-Democratic paper. Michigan, in common with the other states of the Old Northwest, had many alien-born voters, and it is generally conceded that the Republicans profited most from this vote. But the Michigan Dutch had been sympathetic to the Democrats and Scholte was engaged in order to help secure this vote for "Buck and Breck."

The Reverend Mr. Scholte was not unknown to the Dutch settlers in Michigan. In the early days of the migration to the United States, Scholte had made overtures to some of the Reverend Albertus C. Van Raalte's followers, urging them to settle on the prairies of lowa rather than among the forests of Michigan. Largely because of their personal loyalty to him and, in part because of their poverty, the newcomers preferred to follow Van Raalte, rather than move on to the lowa settlement. Van Raalte was primarily a pastor, interested in building up his church and laying the foundation for what was to become Hope College. Scholte, on the other hand, had had some experience in the field of lowa politics. Thus, it was good strategy on the part of the party leaders in Michigan to ask Scholte for his aid in appealing to his fellow Dutchmen for their support of the Democratic ticket.

Scholte evidently was a man of many talents. During the two decades that he lived in Marion County, lowa, he was not only a minister and newspaper editor but also dabbled in manufacturing enterprises, banking, insurance and real estate. In addition he served in various minor governmental positions. ${ }^{4} \mathrm{He}$ had espoused Whig political views at one time but after the organization of the

${ }^{3}$ In the next 80 years, the Republicans won every gubernatorial election save 3. McClelland resigned as Governor on March 7, 1853 to accept appointment as Pierce's Secretary of the Interior.

${ }^{4}$ The Allegan Journal of October 8, 1856 referred to. Scholte as a "mammon worshipping pastor." 


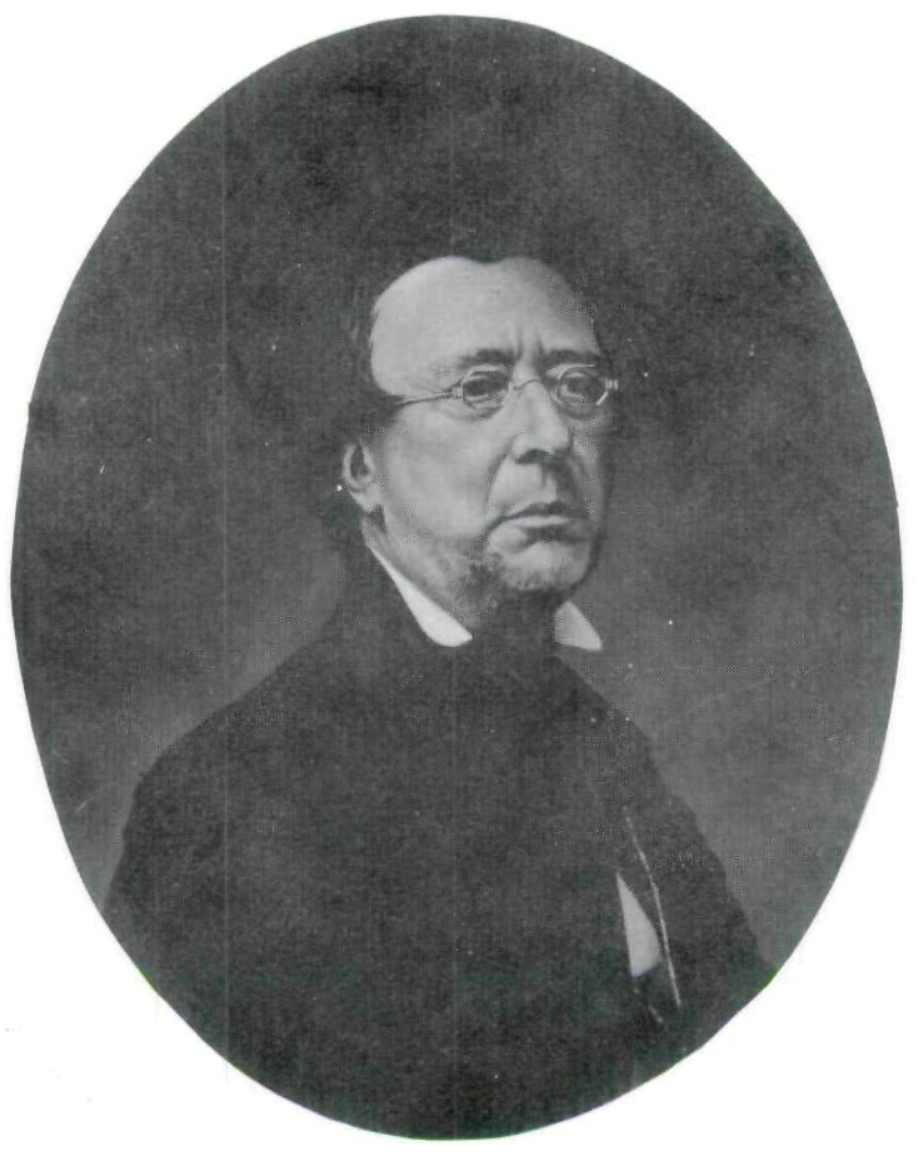

H. P. Scholte

Picture courtesy Department of History and Archives

Republican Party in lowa he became a Democrat, largely over the prohibition and Know Nothing issues. ${ }^{5}$ Scholte launched his journal, the Pella Gazette, on February 1, 1855 and it was to continue, with some breaks, until nearly the end of February five years later. It was

${ }^{5}$ Robert P. Swierenga, "The Ethnic Voter and the First Lincoln Election," Civil War History, XI, (March, 1965), 29-35. 
not a financial success. Although its masthead proclaimed "Independent in Everything," the paper began as a Democratic publication and ended up as a Republican organ-within the space of five years! ${ }^{6}$

Before coming to Michigan, Scholte was supporting the candidacy of Buchanan in the Pella Gazette. In the June 26, 1856 issue he editorialized on "Our Reasons for Sustaining Buchanan for President." In a manner common to many of his writings, he first chastised "political blackguards" who were "misguided by false representatives," and then "for the benefit of honest men" gave his reasons for the support of the Democratic ticket. Cutting through .the verbiage, the reader discovers that Scholte had "not changed [his] opinion in reference to American Slavery. We yet hold it to be the worst system of Slavery that ever existed," and thought it "desirable to have it removed by honorable means ..." He then referred to "different isms, whose only rallying point is opposition to the present government ... Slavery is the pretext; political supremacy is the object." Scholte declaimed against the Abolitionists who, he felt, "disregard[ed] the holiness of the Bible . . . ." In discussing the troubled conditions in Kansas, he noted that "Abolitionism will not stop in Kansas," and went on to arraign the Abolitionists for not "acting according to the provisions of the Constitution ... . In contrast, according to Scholte, the Democratic Party "rallys around the Constitution, and knows no distinction of North, South, East or West . . . An old known and tried statesman is the standard-bearer." Having thus justified his support of Buchanan, the Reverend-editor concluded:

We consider it our duty to resist the attempt of the fusionists to plunge this glorious republic into the horror of a fratricidal war, and we have no doubt that the people upon sober second thought will give a large majority for BUCHANAN and BRECKINRIDGE!

What was the attitude of the Hollanders-and Scholte in particular-toward slavery as an institution? Coming from a land which had for centuries championed the cause of freedom, it could be assumed that the Dutch would be opposed to a system of bondage and, in general, this was the case. ${ }^{7}$ In 1855 , the Classis of Holland of the

\footnotetext{
${ }^{6}$ Lubbertus Oostendorp, H. P. Scholte, (Franeker: T. Wever, 1964), 183.

${ }^{7}$ Jan Van Hinte, Nederlanders in Amerika, $(2$ vols.; Groningen: P. Noordhoff, 1928), I, 456.
} 
Reformed Church in America had protested the acceptance of eight South Carolina congregations because of "the curse of slavery." 8 However, because of their Calvinistic predilection, many of the immigrants felt that the Biblical curse on Cain gave approval to a system of servitude. If the Scriptures condoned slavery, there was to be no questioning of the matter.

Scholte adopted an ambivalent attitude toward the institution of slavery, citing St. Paul in his argument. ${ }^{9}$ While he recognized the existence of slavery, he wished to limit it to the states where it was already in existence ${ }^{10}$ and, in an autobiographical account, he wrote, "I have always been an opponent of slavery without approving the Abolitionists...."11 In this respect he was accepting the arguments of that anti-slavery element which, although strongly opposed to the institution, felt that it could not be legally abolished, and so wished to limit it by preventing its further extension; this was the opinion of many in the new Republican Party. On the other hand, Scholte also subscribed to the theory of popular sovereignty and defended that principle in a speech he delivered while in Michigan. ${ }^{12}$ Three months before this talk the editor of the Des Moines Citizen accused Scholte of supporting slavery as a "Divine and particularly Apostolic institution," to which the Pella journalist retorted in the pages of his paper that he "never belonged to the fanatical fabrication of political gas and humbug" and further that he would "not surrender to the base and insipid vituperation of the sychophants of Black-Know-Nothing-Republicanism." 13

It is entirely possible that the question of slavery was not the predominant consideration of the Michigan Hollanders. The Know Nothing Party, espousing a nativist philosophy, had had a brief flurry of limited success in the mid-fifties. Its origins in the aristocratic Whig Party and its advocacy of more stringent naturalization laws made it anathema to the Dutch. They tended to identify

8 Ibid.

${ }^{9}$ I Corinthians, $7: 21$.

${ }^{10}$ Ironically, Republicans could also, in good conscience, subscribe to this position. H. P. Scholte, American Slavery in Reference to the Present Agitation in the United States, (Pella: 1856). Cited by Oostendorp, 184.

${ }^{11}$ Oostendorp, 185.

${ }^{12} \mathrm{De}$ Hollander, August 27, 1856. Scholte defended popular sovereignty in a speech delivered in Grand Rapids. Grand Rapids Enquirer, Sept. 10, 1856.

${ }^{13}$ The Pella Gazette, June 5, 1856. 
Republicanism with Know-Nothingism. In those areas where the ethnic vote was important, editors of Democratic journals encouraged this feeling of associating the two parties in a common cause. In the columns of his Gazette Scholte repeatedly referred to the "Know-Nothing-Republican" faction; on one occasion he fulminated against the "Abolition-Know-Nothing-Black-Republican demagogues" and hoped that its "fanatical and ... mind-enslaving policy" would "not prevail."1 4

Since Scholte was one of the few vocal Dutch immigrants of the time, it is not surprising that the Democrats in Michigan wished to employ his talents and influence in directing his fellow immigrants to vote for their candidates. Scholte spent better than a week in September of the election year visiting the Dutch communities in Michigan, advocating the candidacy of Buchanan and Breckinridge. On occasions, such as in Kalamazoo, he was but one of many speakers; at other rallies he was the main orator. His itinerary took him to Kalamazoo, Grand Rapids, Zeeland, Holland and Grand Haven; each of these communities having a substantial Dutch element among its total population. On September 5, after arriving in Grand Rapids, he recounted "in the first hour of leisure that I can dispose of" 15 some polls he had conducted on the stages and trains between Oskaloosa and Michigan City and expressed pleasure at the overwhelming support he had garnered for his favorites.

Scholte commenced his campaigning on September 5 in Kalamazoo; this community had been the scene of a mammoth Republican gathering the previous August 27, when Abraham Lincoln made his only Michigan appearance. The Democrat rally had been well advertised and thousands of the faithful were present. ${ }^{16} \mathrm{De}$ Hollander, a Dutch language journal published in Holland had advertised in an optimistic tone that the vice presidential candidate, John C. Breckinridge, Senators Lewis Cass and Charles E. Stuart, and

$14 \mathrm{lbid}$

15 Ibid., Sept. 11, 1856. The 5 th of September was the date of a large Democratic rally in Kalamazoo and a busy day for the lowa editor.

${ }^{16}$ The Grand Rapids Enquirer for Sept. 3 advertised "Democrats desiring of going to Kalamazoo ... and have no means of conveyance, will please report themselves to the Committee, in order that teams may be provided." A rival Grand Rapids paper reported that the contingent comprised "151 men, women and boys, 64 horses, the band, a small sail vessel and a large cask of whiskey! The whole number of carriages, sail craft included, was 26!" The Grand Rapids Eagle, Sept. 4, 1856. 
gubernatorial candidate Alpheus Felch would be present and that invitations had been extended to Horatio Seymour and Martin Van Buren "as well as to other illustrious individuals."1 7 Another Democratic sheet proclaimed ". . . let us have a great and glorious gathering-one that will spread consternation in the camp of the Disunion Fremont Republicans."18 Enroute to Kalamazoo, Scholte was joined at Michigan City, Indiana, by Senator Cass and Breckinridge; the group arrived in Kalamazoo about eleven o'clock in the morning. Scholte was conducted to the home of former governor Epaphroditus Ransom, where he dined and then proceeded to Bronson Park, the site of the gathering.

Despite the less than ideal weather-rain fell intermittently during the afternoon-the gathering was considered a huge success by the Democratic press. Some enthusiasts alleged that between twenty and thirty thousand were present; according to the Niles Republican, ". . . the candid estimate of the men of Kalamazoo was about 10,000."19 There were "five delegations of young ladies all dressed in white." 20 Speakers held forth simultaneously from at least three separate platforms. Supporters of the rival Fremont were numerous and did not hesitate to heckle the orators. Scholte spoke in Dutch from one of the stands and in typical fashion expended considerable time in furnishing background material. ${ }^{21}$ "He spoke in clear and unmistakable language of the formation of both parties, he explained the origins of the Missouri Compromise, he described the attitude of the Democratic party respecting immigrants, how sectional the Republican party was . . . ."22

The oratory continued in the evening with Scholte addressing himself to a group assembled in the Fireman's Hall; it apparently was not a partisan gathering. Kalamazoo was a Republican stronghold.

${ }^{17}$ Issue of Aug. 27, 1856-the date of Lincoln's appearance in Kalamazoo.

${ }^{18}$ The Paw Paw Free Press, Aug. 25, 1856. Another quotation from this issue illustrates editorial sentiment of the time: "What is the great cohesive paste of that amalgamation of bastards? Opposition against our . . . government and a desire to break from the Democratic party."

${ }^{19}$ The Niles (Michigan) Republican, Sept. 13, 1856.

20 The Democratic Expounder (Marshall, Mich.), Sept. 11, 1856.

21 "Speaking was had at the same time on the side stands by eminent speakers, among whom was the gifted Scholter [sic] of Wisconsin [sic], Editor of the Pella Gazette." The Paw Paw Free Press, Sept. 8, 1856.

${ }^{22} \mathrm{De}$ Hollander, Oct. 1, 1856. (This was a belated version of the meeting written by "Hawck Eye"). 
The first state Republican party was organized in Michigan following a conference held in Kalamazoo in late June of $1854 .^{23}$

It was soon evident that some 'Fremonters' were present because, as soon as Rev. Scholte began to speak, they began to make such loud noises ( $\mathrm{I}$ am tempted to use the word 'gruntings' because it sounded so much like swine) that it was almost impossible to understand anything. ${ }^{24}$

It was inevitable that some heckling of the Democrat orator would take place.

A tobacco smoker ... still holding his pipe in his mouth, said 'Sir, I cannot agree with what you have said. I had thought that the Rev. Scholte would have told us the truth concerning each party and would have advised the middle road.' Rev. Scholte asked him in what respect he had not spoken the truth whereupon the smoker answered, 'I am not learned enough to do that' whereupon ... Scholte quoted a couplet from Bilderdijk [a Dutch poet] . . This so pleased the audience that nothing could be heard but laughing and clapping and our friend had had enough. ${ }^{25}$

The day after the Kalamazoo mass meeting, Scholte took a stage coach to Grand Rapids, Michigan, and that same evening delivered a political address. The next day was a Sunday and he did not campaign. He preached in the First Reformed Church, but on the following Monday he was again promoting Buchanan, holding forth at the Democratic Hall, in both the English and Dutch languages. A brass band opened the program that night and a choir offered some selections between Scholte's two speeches. Scholte's dual role as minister and politician did not go unnoticed by the press. "We presume it is all right for ministers to meddle with politics, whenever one can be found possessing so little of the spirit of Christianity as to be able to aid the cause of slavery extension," observed a Grand Rapids editor. ${ }^{26}$ Referring to the Kansas question, Scholte said that the real issue was

shall the inhabitants of any territory have the right to decide for

${ }^{23}$ Willis F. Dunbar, Michigan (Grand Rapids: William Eerdmans Publishing Company, 1965), 419.

${ }^{24}$ De Hollander, Oct. 1, 1856.

${ }^{25} \mathrm{Ibid}$. The verse referred to by Scholte urged one to be "a crawler or a climber" but to at least be going somewhere!

${ }^{26}$ The Grand Rapids Daily Enquirer, Sept. 10, 1856. In a slightly less acerbic note another Michigan editor wrote "The Rev. Mr. Scholte, a Buchanan stump orator, made a political speech at Grand Rapids last Saturday, preached on Sunday, and made another political speech on Monday." The Allegan Journal, Sept. 24, 1856. 
themselves what kind of domestic institutions they will prefer or reject, or shall the Congress of the United States have the power to prescribe the rule which shall govern them-the Democratic Party hold the first, the Republican the last, [and] that in the present condition of the territory a fair election cannot be held . . . ."27

He spoke "in a peculiarly animated, eloquent and pointed manner, and ... made a strong impression," according to a reporter for a Grand Rapids newspaper. ${ }^{2} 8$

After his speaking engagements in Grand Rapids, Scholte journeyed to Zeeland, a community almost entirely Dutch, in the company of a fellow clergyman and countryman, the Reverend Cornelius Van der Meulen. He stayed at the home of Jannes Van de Luyster $^{29}$ It is reasonable to assume that the two ministers reminisced about their earlier days for they had been acquainted in the Netherlands. The evening of the day after his arrival Scholte addressed a gathering at the schoolhouse and on Wednesday he made the short trip to Holland, another predominantly Dutch settlement, founded by Van Raalte. Van Raalte and Scholte had at one time been fellow theological students at the University of Leyden. At Holland, Scholte:

was received with much real enthusiasm, although there was no studied or formal display. There were many to whom the sight of his once familiar face recalled to memory's eye the stirring scenes of the struggle with the king and the established church which led to their Exodus [sic] to America. To such, this was a happy reunion with their old leader, in this land of civil and religious freedom. ${ }^{30}$

In light of these connections and mutual sentiments, it is not surprising that the residents of Holland turned out in large numbers to hear the leader of the lowa Dutch settlement. Surely Scholte was in his element. He delivered a lengthy discourse on the history of the United States and its political parties and, having supplied this background information, proved-at least to his own satisfaction"that the Democratic party is the only national party, and that the so called Republican party is but a fusion of discordant elements,

${ }^{27}$ The Grand Rapids Daily Enquirer, Sept. 10, 1856.

$28 \mathrm{lbid}$. In an editorial appearing in the Sept. 18, issue of his paper, Scholte wrote that he had received "unmistakable signs of approbation."

${ }^{29}$ Van de Luijster was the financial "angel" of the Zeeland settlement. An unassuming individual, he never permitted a photograph to be taken of himself.

${ }^{30}$ De Hollander, Sept. 17, 1856. 
only held together by the hope of the spoils of office." ${ }^{1} 1$ The Dutch in "De Kolonie" were as eager to hear Scholte preach as deliver speeches, so the next morning he preached in the beautiful and historic Van Raalte Church, which now belongs to the 9th Street Christian Reformed congregation.

Scholte ended his Michigan campaigning in Grand Haven where approximately 200 Dutchmen attended a meeting held on Saturday, September 13. The Grand River Times advertised that the subject would be "Politics" and one can well imagine that Scholte took advantage of the latitude afforded by this topic-especially since he addressed the assemblage in his native language. He spoke again on the following Monday, this time in English. The editor of the Grand River Times reported:

His address, as acknowledged by both political parties, was an extremely fair exponent [sic] of the principles of our government; and our political history for the past half century was given with admirable accuracy-exhibiting on the part of the Hon. gentleman, a political knowledge of the country of his adoption that is possessed by very few, even of our grey headed patriots and politicians. ${ }^{32}$

The editor of the Democratic newspaper in Holland editorialized:

We have received oral and written testimony to the influence he exerted... The well known Capt. [Thomas W.] White, a Republican from the beginning, testified that everything the Hollander said was the full truth. It is of significance that his reasoned explanation will further the cause of the party which strives for the maintenance of the Union and the Constitution. All will perceive that the Democratic Party is anti-revolutionary and that the Republican Party is revolutionary and divisive. It is no cause for wonder that enlightened men are more and more coming over to the Democratic Party.

The actions of a clergyman taking to the political hustings attracted the attention of partisan editors in those days of "advocacy" journalism. One of these critics was Jacob Quintus, the editor of the Sheboygan (Republican) Nieuwsbode. "The Hollander and its readers seem to hold the language of Scholte as that of an oracle." 34 In one issue of his paper Quintus included two stanzas from a derogatory effusion, entitled "What Times, What Morals,"

${ }^{31} \mathrm{Ibid}$.

${ }^{32}$ The Grand River Times, Sept. 24, 1856.

${ }^{3} \mathrm{De}$ Hollander, Sept. 17, 1856.

${ }^{34}$ The Sheboygan Nieuwsbode, July 29, 1856. Cited by Oostendorp, 183. 
sent in by F. H. Grooter, a correspondent from Grand Haven. The writer wondered why the Reverend Scholte had deserted his pulpit and the winning of souls to squander his time in talking about slavery. ${ }^{35}$ On another occasion Quintus pondered "Who would have thought that .. Scholte would come to America as a minister to lay his shepherd's staff in a corner?"36 Scholte was criticized for being "a modern demagogue, who on the basis of God's word holds that the detestable institution of slavery with all its abominations is not sinful." 37 A couple of weeks after Scholte's appearance in Kalamazoo, the Gazette of that city ran an article concerning pulpit politicians and quoted Jefferson: ". . . it is not too much to say that the clerical influence... is being actively and ingeniously exerted in our politics, cast as it is into the scale of fanaticism and proscription ...."38 A Republican resident of Wisconsin wrote Quintus regarding Scholte that he

raises my admiration to the skies when I think of the Netherlands where he preached the Gospel in spite of fines and imprisonment, and see how now in a country where we have more freedom of religion he deserts his pulpit to become an attorney, publish a paper, (and) gad about speaking in behalf of a party which extends slavery."

Scholte could be venomous too. A Jackson (Michigan) editor referred to him as a "tyrannical ecclesiastical" ruler, whereupon Scholte retorted that "The editor of the Jackson Citizen must be prominent in the order of Know-Nothings, and if Michigan has many such champions in the present presidential contest, then that State can boast that it beats any other State of the Union in the number of its blockheads." $" 40$ Replying to those critics who accused him of mixing spiritual and temporal matters, Scholte "... . begs $\mathrm{Mr}$. Quintus ... to notice that any man, even a clergyman, may express his candid opinion on political matters; but that no man, and least of all a Dutchman, should sell his principles and his countrymen for a fat office.", 1

\footnotetext{
${ }^{35}$ The text of this poetry (?) may be found in Henry Beets, "H. P. Scholte's Leven and Streven in Noord-Amerika," Nederlands Archief voor Kerkgeschiedenis, XXIII, 267.

${ }^{36}$ Oostendorp, 184.

${ }^{37}$ Beets, 267.

${ }^{38}$ The Kalamazoo Gazette, Sept. 26, 1856.

${ }^{39}$ Nieuwsbode, Oct. 7, 1856.

40 The Pella Gazette, June 12, 1856.

${ }^{41}$ Ibid., June 5, 1856.
} 
How successful was Scholte in his efforts to persuade the Michigan Hollanders to support the party of Buchanan? The editor of an Allegan County Republican paper opined that "well paid and pampered U.S. Government officials will have no weight among the intelligent and industrious Hollanders . . . of Michigan ... . ."42 The editor of De Hollander asserted that the influence of the "perceptive and honest Scholte" was worth hundreds of votes. But it would appear that Scholte was not concerned to win over his fellow Dutchmen to the Democratic Party but rather to keep them faithful to the party and reject the blandishments of the Republicans. At least, this was the judgment of the Paw Paw (Michigan) Free Press, a Democratic paper. After praising the industry and intelligence of the immigrants who had arrived only a decade before, the journal noted "That they are the very best of American citizens is clear from their political posture." 43 In the Dutch settlements of Holland, Zeeland and Fillmore the Democrats did eke out a small majority. But in Grand Haven, Grand Rapids and Kalamazoo the Hollanders generally supported the Republican slate. Writing from Grand Rapids, at the time of his visit there, Scholte had satisfied himself that "the great majority of Hollanders are safe for Buchanan." 44 The Allegan Journal noted that Buchanan had a majority of only 102 in the entire Holland colony. "Allegan and Ottawa Counties have both gone Republican." 45 Hermanus Doesburg, the querulous editor of De Hollander, who had echoed many of Scholte's sentiments, conceded that the "Democracy of Ottawa County have [sic] suffered a most disastrous defeat; a complete annihilation .... ."46

Scholte was able to adjust to the defeat of his candidates in Michigan because nationally they achieved success: James Buchanan had been elected President. Commenting on the election results Scholte was quoted in one friendly paper as alleging that ". . . the real issue was sovereignity of the people or Congressional supremacy . . . Republicanism will soon vanish." ${ }^{\prime 7}$

But "Republicanism" did not vanish. The new Republican Party

${ }^{42}$ The Allegan Journal, July 30, 1856.

${ }^{4} 3$ The Paw Paw Free Press, July 7, 1856.

${ }^{44}$ The Pella Gazette, Sept. 18, 1856.

${ }^{45}$ The Allegan Journal, Nov. 14, 1856.

${ }^{46}$ De Hollander, Nov. 19, 1856.

${ }^{4} 7$ Ibid., Nov. 26, 1856. 
won the Presidency four years later and exerted an almost unbroken dominance over national politics for more than a half century. It is not within the scope of this article to treat of events in the four years following Scholte's efforts in Michigan. However, even though he once castigated the new Republican Party, he deserted to its ranks by 1860 . He served as one of the vice presidents at the convention which nominated Lincoln, attended the Lincoln inaugu$\mathrm{ral}$ and was rewarded with appointment as minister to Austria, an appointment which the Senate failed to confirm.

The national election of 1856 proved that the Republican Party was a sectional one. In Michigan the party won a majority of local and state offices as well as casting its presidential preference for John C. Fremont. Scholte had been called to solidify the Dutch vote for the Democrats and, on the basis of the election returns, it appears that he was somewhat successful. At least there was a small Democratic majority in those areas where there was a concentration of Dutch settlers. ${ }^{48}$ However, the lingering effects of the KnowNothing movement cannot be overlooked in accounting for this vote. Scholte reinforced this feeling of suspicion among the Michigan Dutch. But the Republican tide was running strong. In spite of the Dutch vote, the counties in which they lived provided Republican majorities. Scholte had been successful in actomplishing what he had set out to do. But this was only the winning of a political skirmish. The victory in Michigan was to go to the Republicans.

${ }^{48}$ /bid., Nov. 12, 1856. 
Copyright of Annals of Iowa is the property of State of Iowa, by \& through the State Historical Society of Iowa and its content may not be copied or emailed to multiple sites or posted to a listserv without the copyright holder's express written permission. However, users may print, download, or email articles for individual use. 